\title{
The Effective Use of Authentic Materials in the English Language Classrooms
}

\author{
OPEN ACCESS \\ Parupalli Srinivas Rao \\ Lecturer in English, English Language Centre \\ King Faisal University, Al-Hasa, Kingdom of Saudi Arabia
}

Volume: 7

Issue: 1

Month: July

Year: 2019

ISSN: $2321-788 \mathrm{X}$

Received: 15.06.2019

Accepted: 24.06.2019

\section{Abstract}

Due to the technological innovations, the twenty-first century has witnessed tremendous changes in all walks of life. The new technology abetted the extant educational system and it gifted the contemporary educational system with a newfangled drift. As a result, there have been several innovations in the field of education and English has no exception. The concept of teaching English has drastically changed and the present generation of teachers as well as the learners depend more on the latest technology that brings a greater change in teaching and learning. In the modern world, the teachers of English have been using a variety of teaching materials in order to satisfy the needs and interests of the learners. In this process, they also go for the authentic materials in addition to the prescribed textbooks with an aim to improve the standards of the learners and to develop their learners' language skills enormously in the regular English classrooms. According to Peacock (1997), "Authentic materials are more motivating for students, even lower level students, than artificial materials". Furthermore, Briton (1991 cited in Qura, 2001) states, "Authentic materials relate more closely to learners' need, for they build a connection between the language classroom and the outside world. The teachers have to use all the available authentic materials such as newspapers, magazines, story books, movies, radio, TV ads, songs, label products, bus or train timetables, realia like phones and dolls so that the learners show more interest towards their leaning. As authentic materials play a vital role in promoting the learners' learning and creates interests among learners to learn the English language in a natural way with proper motivation, the teachers of English should use theseauthentic materials in their day-to-day teaching profession. The present paper brings to light to the effective use of authentic materials by the teachers in the English language classrooms. For this purpose, this paper initially discusses the advantages of authentic materials in the field of education. Then this paper brings out the importance of the authentic materialsthat are used in the English language classrooms. Later, this paper emphasizes primarily on the effective use of the authentic materials and how they assist the teachers in their teaching and also how they help the learners to learn English in a better and easier way. Finally, this paper gives some expedient hints both to the teachers and the learners of English to how improve their teaching and learning skills colossally using the authentic materials in the English classrooms.

Keywords: authentic materials, English classrooms, learners, teachers, technology.

Humanities, vol. 7, no. 1, 2019, pp. 1-8.

DOI:

https://doi.org/10.34293/ sijash.v7i1.556

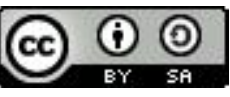

This work is licensed under a Creative Commons Attribution-ShareAlike 4.0 International License

\section{Introduction}

In the present digital era, technology paved a new dimension in almost all the fields and the field of education has highly benefitted in bringing drastic changes in teaching and learning. With the introduction of the internet and computers in education, the teaching and learning has become easy and accessible for all the teachers and learners of English. The teachers have been using the internet to download materials, update their knowledge, get immediate solutions for their doubts and queries, show the required pictures, videos and audios to the learners, give Power Point presentations, record the learning process of the students and so on. After the introduction of the mobile phones or smart phones, there is a tremendous change in the learning style of the learners. The learners are able to learn the language both in and outside the classrooms. 
As the present generation of learners gets the opportunity of using numerous sources to learn any subject, the use of authentic materials seems to be a great help for them to improve their learning skills. The teachers can use the authentic material as additional material to develop the overall skills of the learners' learning. With the help of the authentic material, the teachers can reinforce the learning items and can give additional tasks to the learners. Furthermore, these authentic materials create interest among the learners since the teachers select them with proper care by taking the needs and interests of the learners. As a result, the learners can participate with more enthusiasm in the given tasks and try to perform the tasks with utmost care and concentration. Authentic materials are abundantly used in the teaching of English by the teachers to attain better results while teaching the learners in the English language classrooms.

\section{Materials Used in the English Language Teaching}

The concept of teaching a subject generally depends on the analysis of the nature of the particular subject, its teaching and learning doctrinesingrained in research and the theories related to philosophy and psychology of education. Teaching-learning materials constantly deal with methods, approaches, materials, syllabus and evaluation. Language teachers use two types of materials, i.e., the materials that are exclusively prepared to teach a language, for example textbooks and authentic materials such as newspapers, brochures, pamphlets, etc. that are used for the purposes other than teaching but are often used in the language classrooms while they teach a language. The materials used in the classroom are especially prepared by the subject experts of the English language to meet the needs and requirements of the learners. Even though these materials provide standard information, they are monotonous. In motivating the learners, the materials prepared by the subject experts and they fail to present the realworld or situational language and it leads to teachers' burnout. Therefore, it is more essential for the language teachers to prepare their own materials for their teaching according to the needs and interests of the learners and also according to the demands of the prevailing society.
As the normal and prescribed materials do not satisfy the needs and interests of the students, the teachers of English have to prepare some additional materials on their own. In this context, authentic materials are so useful for them to use in their classrooms. The teachers of English can adopt materials on the needs of the learners so that the learners can work on the given materials with a lot of interest and more enthusiasm. Indeed, authentic materials provide very good resources for ELT teachers and they give the learners an opportunity to expose to the real-life and out-of-classroom contexts. The main focus of the authentic materials in ELT classrooms is to convey the meaning of the message and to communicate the message according to the context. When authentic materials are provided for the students, undoubtedly they will surely use English in real-life situations. Moreover, the learners develop their language skills enormously and communicate not only with their peers in the classrooms but also with friends, family members and other people outside the classrooms.

\section{The Sources of Authentic Materials Used in the ELT Classrooms}

Since the authentic materials are more economic and effortlessly available anywhere and anytime, the teachers of English can use them to teach in their regular ELT classrooms. There are many authentic materials available to teach English such as News Papers, Brochures, Pamphlets, Flyers, Advertisements, Greeting Cards, Invitation Cards, Post-Cards, Wall Papers, Comics, Cartoons, Story Books,Agony Columns, Directories, Maps, Magazines, Journals, Pictures, Audio Cassettes, Images, TV Programmes, TV Ads, Movies, Songs, Internet Notices,Bus or Train Timetables, Recipe, Menus, Stamps, Tickets, Product Labels, Realia such as phones and dolls,Currency, Weather Reports, Puppets and so on.

\section{The Main Advantages of Authentic Materials in the ELT Classrooms}

As authentic materials are selected by the teachers according to the needs and interests of the learners to involve them in learning the English language skills and to demonstrate their skills in 
and outside the classrooms, the English language classrooms, they are frequently adopted in teaching the English language using real-life situations. Using authentic materials in the ELT classrooms have several advantages. They are:

- Authentic materials are selected according to the needs and interests of the learners.

- They are useful to minimize the level of hesitation among the learners.

- They always provide situational language for the learners.

- The learners are exposed to real-life situations.

- They are very economical to use in ELT classrooms.

- They are easily accessible for the teachers.

- They are available everywhere.

- They are very much helpful to develop social language skills.

- They develop the learnersability to interpret the topic they learn.

- They enhance the learners critical thinking.

- They develop creativity among the learners and the teachers.

- They make the learners aware of the situation in the society.

- They are useful for the teachers to teach the same material for different classes.

- They promote the learners to concentrate more on the language skills.

- They always motivate the learners to read for pleasure.

- They are easily available everywhere.

- They promote the learners with higher level of motivation.

- They are more useful for the students who are very slow learners.

- They promote the average learners to perform well.

- They enhancethe ability of explanation and conversation of the learners.

- They support an artistic approach to ELT.

- They make the teaching and learning process easy and interesting.

- They produce a sense of achievement among the learners.

- They are more useful for the teachers to prepare alternate materials.
- They offer variety of language contexts, registers, genres and styles of both written and spoken discouses.

- They are more useful for the learners whose previous knowledge and educational background is very low.

- They really build a connection between the outside world and the English classrooms.

- They promote the learners to take part in the classroom discussions actively.

- They are useful for the teachers to prepare the materials suitable for the learners.

- They serve as mediating artifact for contextualizing English language learning.

- They have a positive effect on learners' motivation.

- They develop the learners' analytical as well as reasoning skills.

- They are generally equipped with sound and pictures so that they are eye-catching and more interesting.

- They encourage the learners to take part in the classroom tasks and perform well in the given tasks.

Since the authentic materials have several benefits and they are very useful to the teachers and learners to improve their teaching and learning skills, the English languageteachers and learnersshould utilize the authentic materials in a properway to yield better results.Eventually, the success of the use of authentic material is on how the language teachers select the relevant authentic materials. Hence, it is high time to discuss the use of the authentic materials by teachers in the ELT classrooms.

\section{The Use of Authentic Materials in the ELT Classrooms}

With the advent of the internet, the teachers of English can choose the authentic materials to teach in their classrooms. Even though there are some disadvantages of authentic materials such as they become outdated (news), they are sometimes too culturally biased, the vocabulary may not be useful for the learners' immediate use and so on, the authentic materials are useful in many ways. Therefore, the teachers of ELT have to carefully select the materials according to the levels and needs 
of the learners. Let us discuss in detail how to make use of some of the authentic materials in the ELT classrooms.

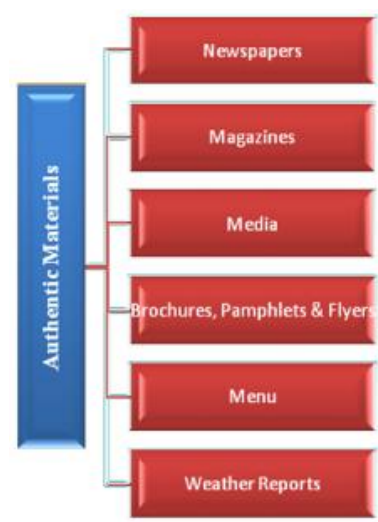

\section{Fig. Authentic Materials Used in ELT}

\section{Newspapers}

One of the best sources of authentic materials which are more useful in the ELT classrooms is the newspapers. Newspapers publish latest and burning news every day and the teachers can adopt the useful news reports as authentic materials to teach the learners of English. Since the language used in the newspapers differ from one news and the other and the vocabulary and grammatical structures also vary from day to day, it enhances the English language learners to grasp and understand the use of language in a variety of ways. Newspapers are also useful for the English language learners to improve their language skills. Newspapers present news on a variety of topics including education columns, sports columns, geographical and historical columns, cultural activities columns, etc. They also present the day-to-day language with all the possible idiomatic expressions of the local culture. The language styles that are found in the newspapers are not to be found in the prescribed textbooks and the newspapers can be analyzed in various ways such as for academic writing as the text for stylistics and semantics. Ever since the newspapers publish news related to reallife events, they arouse curiosity among the learners of English. Moreover, they provide knowledge to the learners and offer a practical way of indulging the learners of ELT in learning the English language in a natural and way. Newspapers are used to develop the English language learners' reading comprehension, writing skills, vocabulary skills, grammatical skills and critical analysis. Most of the learners intend to read the local or regional newspapers since the language used in newspapers is easily understood and comprehensible. The learners can browse the internet and can read regional, national and international newspapers.

The authentic materials taken from the newspapers are useful to give pre-activity tasks which can foster the learning skills of the learners when the material is given for them in the form of assignments. With the help of newspaper articles the learners can improve their vocabulary and the learners can grasp the variety of the presentation of thenews items. Jacob J. S. says, "Newspaper gives the people the eyes to see themselves, gives them the ears to hear themselves and hear to the world, it gives people the voice by which they can make themselves heard in the world". Newspapers are very informational and provide very influential education to the learners. They are the cheapest and most affordable reading materials for the learners to buy. The teachers of English can make use of materials from the daily newspapers such as articles, photographs, pictures and advertisements to teach in the ELT classrooms. Since the print media plays a dominant role in using the authentic materials, theycan be integrated into the ELT classrooms to perform some useful leisuretime activities. Newspapers help the learners to learn the language and they get wonderful practice of the language. Newspapers not only enhance the learners' observation and critical thinking skills but also promote the learners' imagination. Since there are innumerous advantages of using newspapers in the ELT classrooms, the English teachers should make use of the available and useful materials for the learners to promote their language skills efficaciously.

\section{Magazines}

Magazines are enormously used as rich source ofauthentic materials in the ELT classrooms as they are very motivating and inspire a wide range of activities. Magazines help the learners in developing the language skills, vocabulary and grammar. Magazines contain a substantial quantity of information and a wide variety of text types. 
Magazines provide fresh news and reports and news from all over the world instantly. Magazines are an asset to the learners since the learners of English can get an opportunity to familiarize themselves with the latest news and recent reports. Grundy (1993) says, "It is important to develop a wide amount of activities that can be used even if the material is not timely. It is essential for the teacher to think creatively to be able to use a specific activity for a specific text". The teachers of English can make use of the available magazine pictures to perform certain taskseven if the learners' English proficiency is very low to read a magazine. The magazines used in the classroom should be related to the language or teens. The teachers can encourage the learners to select the magazines of their own interest and ask them to read it thoroughly and describe the content of it to the rest of the class. This kind of activity improves the learners' reading comprehension skills as well as summarizing and presentation skills. The teachers can give a list of headlines to the students and a short text or a sentence or sub-headings from each article of the magazine and ask the learners to match them by forming groups or pairs. The materials from the magazines can be used in many ways in the ELT classrooms and the teachers should select the useful and interesting materials for the learners to motivate them in learning the language in a learner-friendly environment.

\section{Media}

Media is used as an additional tool for language teachers to develop the presentation of the materials in the classrooms. Media plays a key role in engaging the learners' learning process of the language. The teachers of English have to select media that are used in teaching and learning process suitable for the learners' needs and interests. The selection of appropriate and proper media motivates the learners' to learn the learning process in a smooth way. The teachers of English should use communicative media to give more information or explanation to the learners to understand the topic easily. Murcia (2001: 461) asserts, "Media tools are physical things used by the teacher to motivate the students by bringing a slice of real life into the classroom and by presenting language in its more complete communication complex". In teaching and learning process, media include computers, games, audiovisuals, graphs, pictures, boards and so on. There are several media used to teach vocabulary such as using games, using visuals (like booklets, pamphlets, brochures, etc.), using flash cards and using pictures and photographs. There are many advantages of using media in teaching and learning English. While teaching English using media as authentic materials, the learners will become more active and enthusiastic. Also, an interesting learning atmosphere is created in the English language classrooms and learners' motivation is increasedusing media.

\section{Brochures, Pamphlets and Flyers}

Brochures, pamphlets and flyersare the best key tools used for language teaching to promote the learners language skills and all of them are used for advertisement that offer a great and real information for the learners. In fact brochures are cost effective and they are widely used in teaching and learning English. Brochures come in numerous shapes and sizes and often come in bi-fold or tri-fold layout used as flyers, coupons or business cards. The teachers can encourage the learners to gather various brochures of museums, banks, libraries, travel agencies, car rental agencies and so on. Then the teachers can select any brochure where the hours of business are clearly visible. By using these brochures, the teachers can introduce several role-plays with the studentsaccording to their interests. This also paves a way to review the days of the week also.

The teachers can also present their learners with a wide variety of travel brochures and involve the learners to talk about each of the destinations. The teachers should give a chance to the learners to select a particular destination and ask them to write about it why they like to travel to that particular place. Using the travel brochure, the teachers can enhance the language skills of the learners. The teachers can also ask the learners to collect some medical brochures from doctors' offices and use them to have some dialogue practices. Once the learners read the brochures in detail, the teachers can give them some comprehension questions to answer. Using the health brochures, the teachers can ask them various warm up questions related to different topics about 
health. Undoubtedly, medical topics are hard to understand for the EFL/ESL learners to understand, medical brochures are written in a very clear and simple language that they can be understood by any language learners. Indeed, medical brochures are the better sources of information for EFL/ESL learners to make better reading material than medical books or encyclopedias. Therefore, the teachers of English should adopt medical brochures as authentic materials as they are more essential for the English language learners not only to develop their language skills but also improve their knowledge about the medical field to prevent from diseases.

\section{Menus}

Menus are available in all the restaurants and many of them have online menus. As food plays a major role in the lives of the people, especially in the lives of the students, the ELT teachers can introduce the menus as their authentic teaching materials. The teachers can motivate the learners to use the menus of the restaurants to have conversation with their peers. Since food is a favourite item for all the learners of English, they are highly motivated and participate activelyin the classroom discussions. The learners also can order for food in the restaurants with more confidence. To introduce an activity using the menus, the teachers have to collect quite a few copies of the menus from different restaurants so that the learners can compare and contrast the price of the food items such as appetizers, drinks, soups, salad, entrees, meals and dessert. The teachers can introduce many activities in the classrooms. The teachers can give a worksheet to the learners and ask them to write down what type of food they can order for from each food station including the price section in it. Then the teachers can divide the classroom into groups so that the learners have to move together from one food station to the other one. The teachers should assign the duty of a waiter or waitress to a member of the group to take orders on the backside or the worksheet at each food station. The teachers should encourage the learners to use a dictionary with them to look up the terms related to food. The teachers act as managers and will be busy in clarifying the queries of the learners who act as customers. Finally, the learners also calculate the capacity of their spending and also learn how to tip the waiter or waitress to have the real experience of the restaurant in the classroom. As the learners of English develop their speaking as well as analytical and reasoning skills using menus in the classrooms, the teachers of English should try to introduce similar activities to enhance the learners' all the four language skills in real-time environment.

\section{Weather Reports}

Due to its audio-visual effects, television plays a major role in using it as authentic materials. The attractive ads, comics, songs, games, movies, weather reports, pictures and so on are of immense use to teach the students in the ELT classrooms. The teachers of English can make use of authentic materials to make the learning interesting and fun in the classrooms with a dash of creativity. Therefore, the teachers can integrate authentic materials into their ESL/EFL classrooms to create interest among the learners by using the material that the learners needed. The teachers can introduce weather reports of different channels as authentic materials and the teachers should make the learners familiar with the climate of their countries by exposing them to the weather reports. Just by browsing the internet, the teachers can get the weather reports of different countries of the world. The teachers can select www. weather.com to know the local, national as well as international weather forecast. This website features not only a wide range of weather reports but also some interesting aftermath disaster analysis. Another salient feature of weather.com is to provide short weather write-ups as well as mini-clips to brush up the learners' listening comprehension. The teachers can make use the weather reports in many ways to enhance the learners' language skills. The teachers can read a weather report or show a video to the whole class and ask the learners to summarize the main important points from the weather report that they have listened or watched. The teachers can teach two or three new vocabulary items from the weather report and then ask the learners to find out at least five new vocabulary items related to the weather condition by dividing them into groups. Later, the teachers can give practical tips on how to prepare for that kind of devastation. The teachers 
can also encourage some enthusiastic learners to present weather reports by supplying them some data. This kind of activities will undeniably advance the language skills of the learners. So, the English language teachers should carefully select certain interested weather reports to their learners to develop their language skills in the English classrooms.

There are many more authentic materials that are useful for the English teachers to adopt them as additional teaching materials in their classrooms and teachers should select some important and expedient materials that are more helpful for the learners. Moreover, the teachers should adopt authentic materials that highly influence their learners in learning the English language and perform well using the learned teaching items in and outside the classrooms.

\section{Conclusion}

In this paper, an attempt has been made to focus on the effective use of the authentic materials by the teachers in English language classrooms. First, this paper has discussed the advantages of authentic material in education. After that, this paper has brought out the importance of the authentic materials in the English language classrooms. Furthermore, this paper has emphasized mainly on the effective use of the authentic materials and how they are useful the teachers in their teaching and also how they help the learners to learn the English language in an easy and different way. Finally, this paper has also given some expedient hints not only to the teachers of English but also the learners to develop their teaching and learning skills colossally using the authentic materials in the English classrooms.

As authentic materials provide the opportunity for the English language teachers to adopt various strategies to teach the learners using the latest techniques in their classrooms, the learners have a chance to learn the language in a novel way. Authentic materials are more economical and easily accessible anywhere and the teachers of English have been using them in their everyday classrooms. The teachers should also promote their learners' language skills enormously by adopting the authentic materials that create interest among the learners. The teachers should make use of the available materials to involve the learners more on the topic taught and encourage them to participate actively in the tasks that are given to them. The learners also should follow the instructions of the teachers and participate in the group or pair activities by doing them collaboratively. As the concept of adopting the authentic materials is to motivate and attract the learners to learn the language in an entirely different way, the learners do the given tasks with more enthusiasm and interest. The teachers should give more independence for the learners in selecting the authentic materials that are available with their teachers. As long as the authentic materials are found interesting for the learners, the teaching and learning will take place in a learner-friendly way. Therefore, the teachers of English are advised to concentrate on the needs and interests of the learners so that their main aim of teaching will be a productive one.

\section{References}

Ajayi, L. "Newspaper as enrichment material for enhancing students' performance in English." Perspectives on Applied Linguistics in Language and Literature, edited by Adebayo, L., Isiugo-Abanihe, I. and Ohia, I. N. Stirlin g-Holden Publishers Ltd, 2002.

Bello, S. "Promotion of Newspaper as Supplementary Teaching and Learning Resources for Quality Education." Journal of Library Educational Media and Information Studies, vol. 1, no. 1, 2010, pp. 51-66.

------. Newspaper: A Complementary Medium for Quality Education: Concept, History \& Values. Lambert Academic Publishing, 2011.

Brown, H.D. Language Assessment Principles and Classroom Practices. Pearson Education, 2004.

Carolyn, C. Using Newspapers in the ESL Literary Classroom. ERIC Digest, 1990, pp. 1-5, http://www.ericdigests.org/pre-9216/esl.htm. accessed March 19, 2011.

Clandfield, C.H. Getting Started in Mass Media. National Textbook Company, 1992.

Ten great activities: teaching with newspaper, Education World.http://www.educationworld. com. accessed August 7, 2010. 
National Policy on Education, Federal Government Press, 1981.

Eveland, Jr, W.P. and Scheufele, D.A. "Connecting News Media Use with Gaps in Knowledge and Participation." Political Communication, vol. 17, no. 3, 2000, pp. 215-237.

Grundy, P. Newspapers. Oxford University Press, 1993.

Guariento, W. and Morley, J. "Text and Task Authenticity in the EFL Classroom." ELT Journal, vol. 55, no. 4, 2001, pp. 347-353.

Hegde, S. and Malagatti, S.M. "Educational coverage in dailies and information- searching habits among students." Media Mimansa, vol. 4, pp. 68-77.

Jourdain, S. "Building connections to culture: A student-centered approach." Foreign Language Annals, vol. 31, no. 3, 1998, pp. 439-50.

Kelly, C. et al. "Effective Ways to Use Authentic Materials with ESL/EFL Students." The Internet TESL Journal, vol. 8, no. 11, 2002, pp. 1-5.

Lindsay Clandfield and Duncan Foord. Teaching materials: Using newspapers in the classroom 1, 2011.

Malhan, P.N. "Professional dimensions and educational news culture." Indian Educational Review, vol. 27, no. 2, 1992, pp. 13-27.

Manoharan, M. Relative effectiveness of print media. Fifth Survey of Educational Research, NCERT, 1988.
Nunan, D. The Learner-centered Curriculum. Cambridge University Press, 1988.

Oura, G.K. Authentic Task-based Materials: Bringing the Real World into the Classroom, 2001.

Peacock, M. "The Effect of Authentic Materials on the Motivation of EFL Learners." ELT Journal, vol. 51, no. 2, 1997, pp. 145-156.

Ram, N. The Changing Role of the News Media in Contemporary India. Indian History Congress, 2011

Raut, N. and Kakade, O. "The Role of Mass Media in Promoting Education.” vol. 4, no. 36, 2012, pp. 10-14.

Sanderson, P. Using the Newspapers in the Classroom. Cambridge University Press, 1999.

Shim, J.C. et al. "A Comparative Analysis on News Values: Comparing Coverage of Education in South Korea and the United States." Korean Social Science Journal, vol. 38, no. 1, 2011, pp. 99-132.

Vernon, S.G. and Donald P.E. Teaching and MediaA Systematic Approach. Prentice Hall, 1980.

Vinod, S.D. Newspaper English in India. Bharathi Publications, 1989.

Wallace, C. "Reading." The Cambridge guide to teaching English to speakers of other languages, edited by R. Carter and D. Nunan, Cambridge University Press, 2001, pp. 21-27. Wangusa, A. and Kajimbwa, M. Newspapers in Education as Approach to Improve Learning Achievements, 2010.

\section{Author Details}

Parupalli Srinivas Rao, Lecturer in English, English Language Centre, King Faisal University, Al-Hasa, Kingdom of Saudi Arabia.Email ID: vasupsr@yahoo.com,vasupsr@gmail.com. 